\title{
Wear Resistance Analysis of A359/SiC/20p Advanced Composite Joints Welded by Friction Stir Welding
}

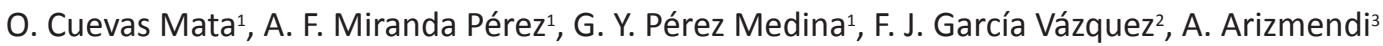 \\ 1 Corporación Mexicana de Investigación en Materiales - COMIMSA, Saltillo, Coahuila, México. \\ 2 Universidad Autónoma de Coahuila - UA de C, Facultad de Ingeniería, Arteaga, Coahuila, México. \\ 3 Cimav-Unidad Monterrey, Apodaca, Nuevo León, México.
}

Received: 08 June, 2016

Accepted: 16 June, 2016

E-mail: octavio.cuevas@alumnos-comimsa.mx (OCM)

\begin{abstract}
Advancement in automotive part development demands new cost-effective materials with higher mechanical properties and improved wear resistance as compared to existing materials. For instance, Aluminum Matrix Composites (AMC) shows improved mechanical properties as wear and abrasion resistance, high strength, chemical and dimensional stability. Automotive industry has focused in AMC for a variety of applications in automotive parts in order to improve the fuel economy, minimize vehicle emissions, improve design options, and increase the performance. Wear resistance is one of the most important factors in useful life of the automotive components, overall in those components submitted to mechanical systems like automotive brakes and suspensions. Friction Stir Welding (FSW) rises as the most capable process to joining $\mathrm{AMC}$, principally for the capacity to weld without compromising their ceramic reinforcement. The aim of this study is focused on the analysis of wear characteristics of the friction-stir welded joint of aluminum matrix reinforced with 20 percent in weight silicon carbide composite (A359/SiC/20p). The experimental procedure consisted in cut samples into small plates and perform three welds on these with a FSW machine using a tool with $20 \mathrm{~mm}$ shoulder diameter and $8 \mathrm{~mm}$ pin diameter. The wear features of the three welded joints and parent metal were analyzed at constant load applying $5 \mathrm{~N}$ and a rotational speed of 100 rpm employing a Pin-on - Disk wear testing apparatus, using a sapphire steel ball with $6 \mathrm{~mm}$ diameter. The experimental results indicate that the three welded joints had low friction coefficient compared with the parent metal. The results determine that the FSW process parameters affect the wear resistance of the welded joints owing to different microstructural modifications during welding that causes a low wear resistance on the welded zone.
\end{abstract}

Key-words: Aluminum matrix composites; Friction stir welding; Wear.

\section{Análise da Resistência ao Desgaste de Juntas de Compostos Avançados A359/SiC/20p Soldadas por Friç̧ão}

Resumo: O avanço no desenvolvimento de peças automotivas exige novos materiais de baixo custo com propriedades mecânicas superiores e com maior resistência ao desgaste em comparação com os materiais existentes. Por exemplo, compósitos com matriz de alumínio (AMC) mostram melhores propriedades mecânicas como resistência à abrasão e ao desgaste, alta resistência e estabilidade química e dimensional. A indústria automotiva tem centrado em AMC para uma variedade de aplicações em peças automotivas, a fim de melhorar a economia de combustível, minimizar as emissões dos veículos, melhorar as opções de design e aumentar o desempenho. A Resistência ao desgaste é um fator importante a determinar para a vida útil dos componentes automotivos, em geral naqueles componentes submetidos a sistemas mecânicos como freios e suspensões. O processo de soldagem por fricção e mistura mecânica (FSW - Friction Stir Welding) surge como um processo capaz de unir AMC, principalmente com a capacidade de soldar sem comprometer seu reforço cerâmico. O objetivo deste estudo é focado na análise de características de desgaste da junta soldada por FSW de matriz de alumínio reforçados com 20 por cento em peso de compósito de carboneto de silício (A359 / SiC / 20p). O procedimento experimental consistiu em cortar amostras em pequenas placas e realizar três soldas nestas placas utilizando uma máquina FSW com uma ferramenta com ombro de $20 \mathrm{~mm}$ de diâmetro e pino de $8 \mathrm{~mm}$ de diâmetro. As características de desgaste das três juntas soldadas e metal base foram analisados aplicando carga constante de $5 \mathrm{~N}$ e uma velocidade de rotação de 100 rpm utilizando um aparelho de teste Pin-on-disk, usando uma esfera de aço de com safira com $6 \mathrm{~mm}$ de diâmetro. Os resultados experimentais indicam que as três juntas soldadas apresentaram baixo coeficiente de friç̧ão comparado com o metal base. Os resultados determinaram que os parâmetros do processo FSW afetam a resistência ao desgaste das juntas soldadas, devido a diferentes modificações microestruturais durante a soldagem, que provoca uma baixa resistência ao desgaste na zona soldada.

Palavras-chave: Compósitos com matriz de alumínio; Soldagem por fricção e mistura mecânica; Desgaste.
This is an Open Access article distributed under the terms of
the Creative Commons Attribution Non-Commercial Licens which permits unrestricted non-commercial use, distribution, and reproduction in any medium provided the original work is properly cited. 


\section{Introduction}

Nowadays, the demand for high strength and lightweight materials is increasing in constantly in automotive and aerospace industry. These materials must have specific qualities such as weight reduction with development in reduction of emissions, improvement comfort, impact resistance, security and energy efficient in terms of reducing fuel consumption. Aluminum Matrix Composite (AMCs) is one of the best options as capable candidate material which has great potential due to diverse features that make them attractive for automotive applications such as low density good corrosion resistance, low thermal expansion and established casting techniques for mass production [1-3]. $\mathrm{SiC}, \mathrm{Al}_{2} \mathrm{O}_{3}, \mathrm{SiO}_{2}, \mathrm{BN}$, and graphite are particles reinforcement that can be used usually in AMCs. Reinforcement can be inserted as either continuous or discontinuous; in short, long fibers or particles for discontinuous [4,5]. These materials present some difficulties associated with their joining, between themselves or with different materials using conventional fusion welding processes, gaining as an outcome reduced joint strength due to solidification shrinkage, porosity, oxide inclusions, distortion, increasing of residual stress, intermetallic compound formations in case of chemical reactions between matrix and reinforcement, being a limit in industrial applications [6]. Opportunely, a new solid state joining process called friction stir welding (FSW) arises to overcome the problems previously mentioned at the moment of joining AMCs [7].

Friction stir welding process consist in a non-consumable hard rotating tool with a specially designed probe that is inserted between the edge of both metal workpieces and travels down the length of contacting, and produces a plastically deformed zone through the associated stirring action and consolidates the retreating side by axial force acting through the tool shoulder [8,9]. When an AMC is joined by FSW it does not reach the melting point, obtaining good results in higher mechanical properties of the deformed material compared with parent the material. The predominant parameters which influence the weld joints properties in friction stir welding are tool rotational speed, welding speed and axial force [10].

FSW process has many advantages in automotive and aerospace industries, including mechanical properties as tensile and fatigue, improved process robustness, lack of consumables, less health and environmental issues, and operating advantages [11].

AMCs materials, in automotive industry, are used to produce components mainly moving and sliding parts, for example, drive shafts, brake drums and cylinder blocks [12]. To produce those automotive components sometimes require the use of secondary operations such as machining, joining, etc., then, it is very important determine the wear characteristics of the weld joint in this kind of materials in order to establish a better understanding of their behavior. A study on wear behavior of AMC's reinforced with hard particles, have demonstrated these materials have more resistance to wear than the aluminum monolithic alloy. This is due to the addition of SiC particle to the aluminum matrix makes it stronger, harder and more resistive to wear [13-15]. The aim of this work is focused on wear resistance analysis of friction stirred joints of an A359 alloy matrix with 20 volume percentage reinforcing $\mathrm{SiC}$ particles [16].

\section{Experimental Procedure}

In this study, plates of an AMC (chemical composition is shown in Table 1) that is produced with an A359 alloy matrix reinforced with $20 \%$ volume SiC particles $(62 \mathrm{~mm} \times 22 \mathrm{~mm} \times 5 \mathrm{~mm}$ ) were employed. They were butt friction stir welded using a special fixture, fixed firmly on the table surface of an FSW machine, as shown in Figure 1. A tool made of High Strength Steel (HSS) presented in Figure 2 was used. The FSW parameters selected in this work are: tool rotational speed $(\mathrm{rpm})$, welding speed $(\mathrm{mm} / \mathrm{min})$ and axial force $(\mathrm{kN})$, which have high influence in the joint properties. The FSW parameters employed for this work are shown in Table 2. Samples of the friction stir welded plates were cut in a length of $20 \mathrm{~mm}$.

Table 1. A359/SiC/20p chemical composition (wt, \%).

\begin{tabular}{ccccccccc}
\hline Element & $\mathbf{S i}$ & Fe & $\mathbf{C u}$ & $\mathbf{M n}$ & $\mathbf{M g}$ & $\mathbf{Z n}$ & $\mathbf{T i}$ & $\mathbf{A l}$ \\
Percentage & $8.5-9.5$ & 0.2 & 0.2 & 0.1 & $0.50-0.70$ & 0.1 & 0.2 & $89-91$ \\
\hline
\end{tabular}




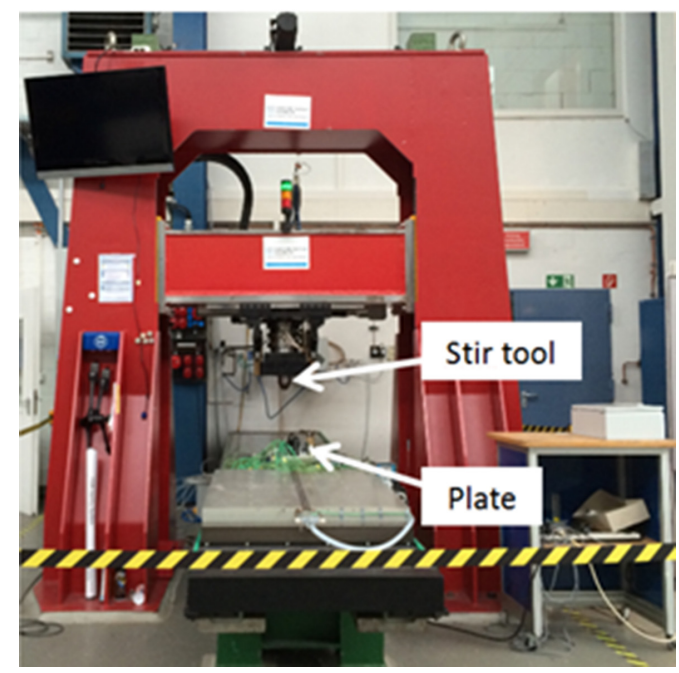

Figure 1. FSW gantry system Helmholtz-Zentrum Geesthacht - Germany.

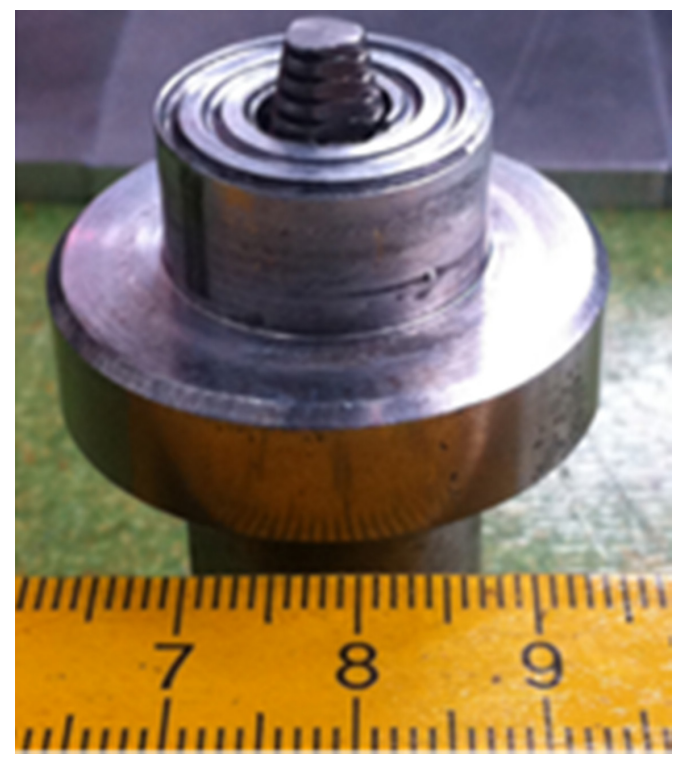

Figure 2. HSS friction stir tool.

Table 2. FSW parameters.

\begin{tabular}{cccc}
\hline Weld & Tool rotational speed $(\mathbf{r p m})$ & Welding speed $(\mathbf{m m} / \mathbf{m i n})$ & Axial force $(\mathbf{k N})$ \\
1 & 1000 & 6 & 8 \\
2 & 1000 & 6 & 10 \\
3 & 1200 & 6 & 10 \\
\hline
\end{tabular}

In this study, the welding speed parameter was kept at $6 \mathrm{~mm} / \mathrm{min}$ applied on the three samples, however, this is a lower value compared with the welding speeds used in other investigation carried out by Ashok and Murugan [17], where they employed 25, 40, 55, 70 and $85 \mathrm{~mm} / \mathrm{min}$.

After finishing friction stir welding on the plates, they were cut to obtain samples which were etched using Keller reagent in order to reveal the microstructure for optical (OM) and scanning electron microscopy (SEM). 
A pin-on-disk tribometer (Anton Paar), as shown in Figure 3, was used to analyze the dry sliding wear characteristics of the friction stir welded zone of the A359/SiC/20p AMC at room temperature according to ASTM G99-05 standard [18]. The dimensions of the three wear specimens were $20 \mathrm{~mm} \times 20 \mathrm{~mm} \times 5 \mathrm{~mm}$ after being machined from the taken samples. The parameters used in the dry sliding wear test were constant load of $5 \mathrm{~N}$, rotational speed of $100 \mathrm{rpm}$, radius $5 \mathrm{~mm}$ and 400 laps. The masses of the specimens were measured with an electronic digital balance before and after applying the wear test. After finishing the test, the specimens were removed from the wear test apparatus and cleaned with alcohol to remove all the debris particles produced by the wear effect. The mass of the specimens was measured at the moment to determine the mass loss.

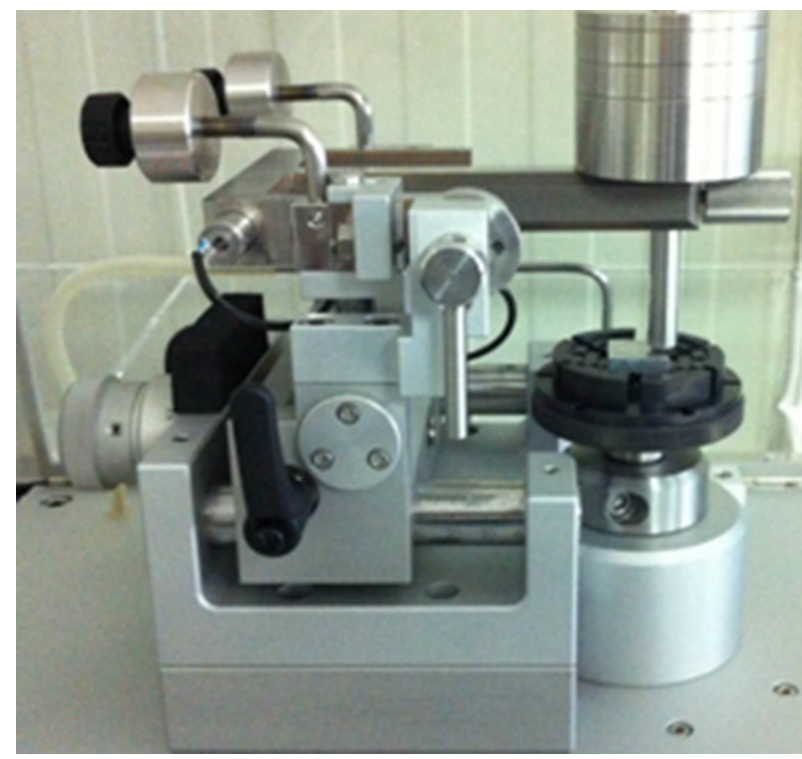

Figure 3. Pin-on-Disk tribometer (Aston Paar).

The specimens wear rates were defined applying the following equation [19] (Equation 1):

$k=\Delta V / F N L$

where $k=$ wear rate $\left(\mathrm{mm}^{3} / \mathrm{N} \cdot \mathrm{m}\right), \Delta V=$ specimen volume loss $\left(\mathrm{mm}^{3}\right), F N=$ normal force applied in the contact $(\mathrm{N})$, and $L=$ distance $(\mathrm{m})$.

The sliding wear analysis of the parent metal was also measured using the same wear parameters used with the others samples.

\section{Results and Discussion}

The friction stir welded joints and their identification number are shown in Figure 4. Figure 5 (a) shows an optical macrograph of sample 2 which is free of friction-stir welding defects; (b) the microstructure shows the matrix of aluminum alloy formed by $\alpha$-phase, in this area exists a homogenous distribution of SiC particles; (c) the HAZ presents SiC particles of different size; (d) in the TMAZ was detected distinct SiC particles behavior in different areas of this zone; (e) the DXZ shows fractured particles in comparison of the parent metal and TMAZ, also the recrystallization was produced by the rupture of SiC particles becoming new grain nucleation sites which leads to the formation of finer grain structure; the particle fracture decreased from the weld center toward the parent metal. Figure 6 shows micrographs obtained by SEM, and the samples after the test are shown in Figure 7.

The rotational speed and the welding speed have the same influence in the heat input and the plastic flow rate. The grain growth, after recrystallization, depends of the frictional heat produced by welding speed and rotational speed, due to a prolonged exposure frictional contact and increased cooling rate. 


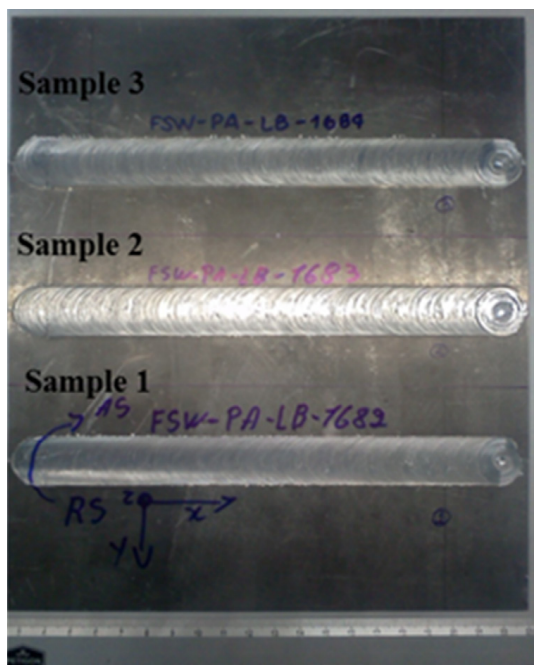

Figure 4. Friction-stir welded joints of A359/SiC/20p plates.

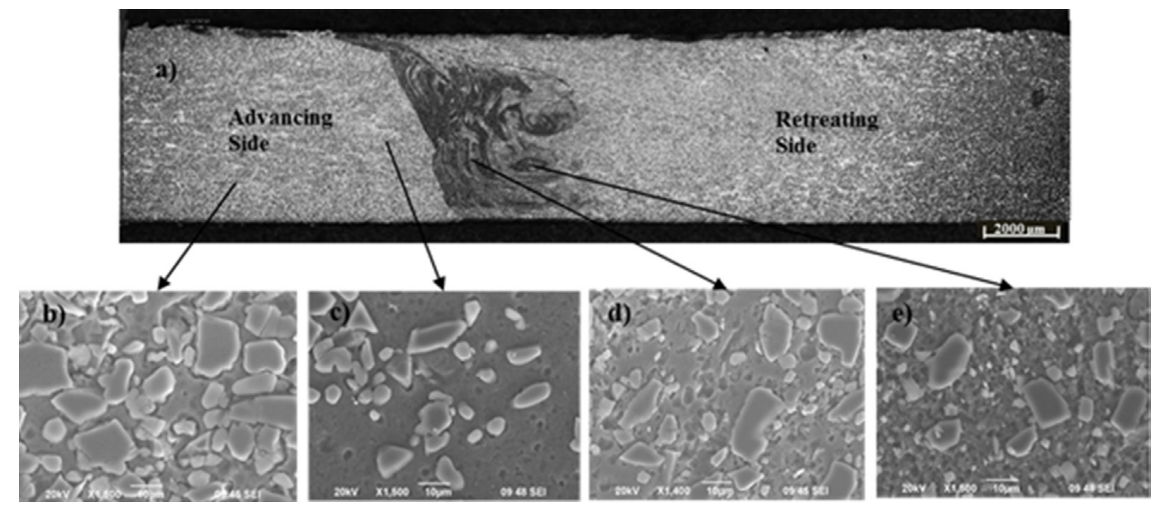

Figure 5. a) Optical macrograph of the Al/SiC friction-stir welded joint sample; SEM micrographs: b) Parent Metal; c) HAZ; d) TMAZ and e) Nugget.
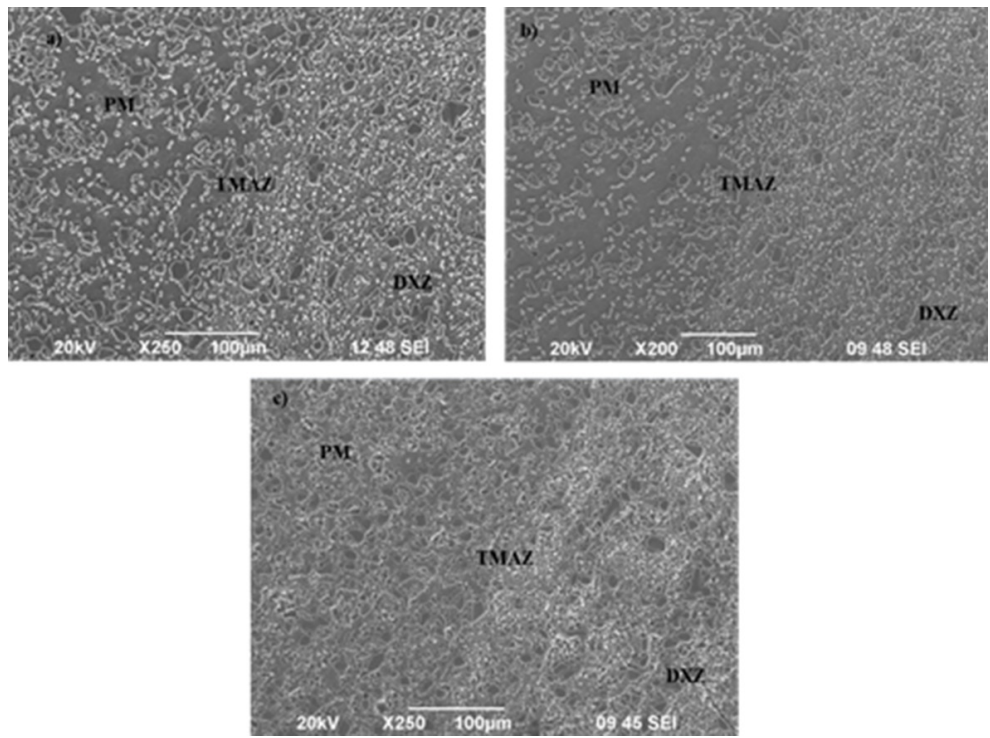

Figure 6. SEM micrographs showing the different zones (parent metal "PM", thermo-mechanically affected zone "TMAZ", and directionally recrystallized zone "DXZ") of friction stir welded joints on the Al/SiC composite. a) sample 1 ; b) sample 2 and c) sample 3 . 


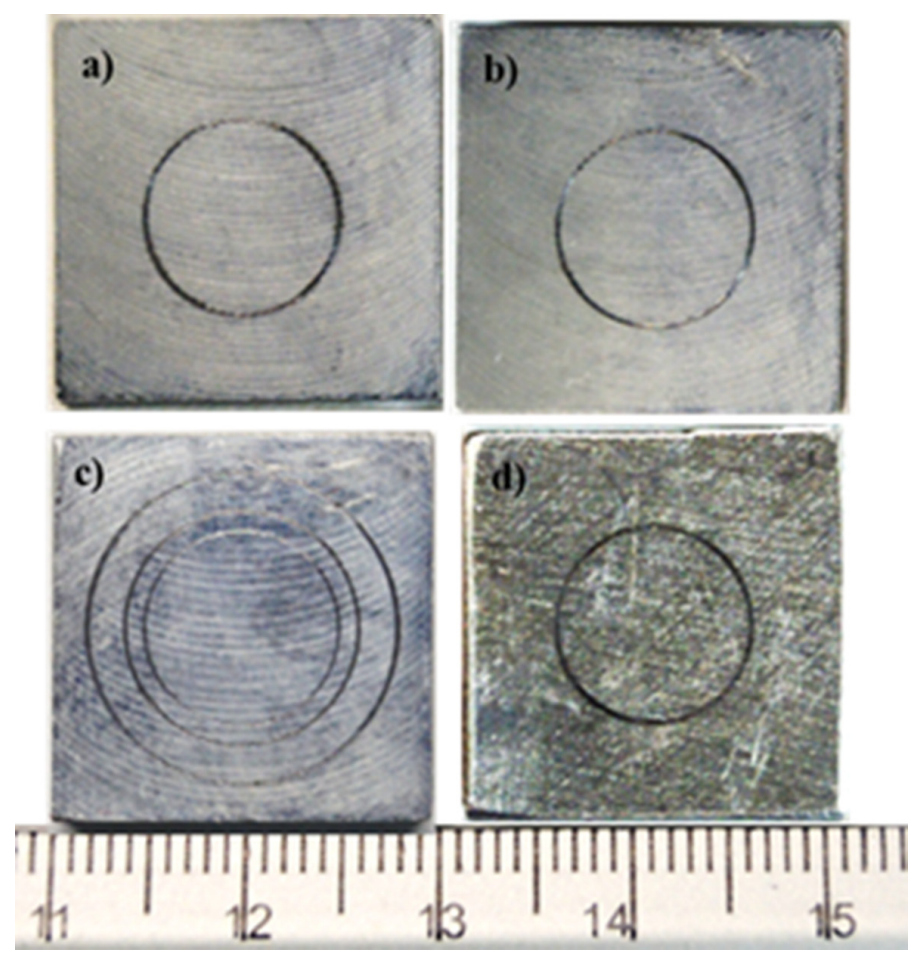

Figure 7. Samples after wear test: a) 1; b) 2; c) 3 and d) parent metal.

The agitation produced a difficult plastic deformation during joining as a result the solid collisions at lower temperature, and it caused the partition of SiC particles, therefore, their size were decreased and their number were increased in the stir zone. The small fragments of SiC particles serve as new grain nucleation site generating a recrystallization.

The samples after the wear test are shown in Figure 7.

The wear resistances of friction stir welded AMC joints and parent metal were analyzed comparing the friction coefficient and wear rate, the friction coefficient results obtained from the dry sliding wear test are shown in Figure 8, and Figure 9 shows the variation of the wear rate. The results demonstrate that the wear rate increases on the welded joint of the examined three samples, and the wear rate of the parent metal is lower compared with the wear rate of the three welded joints.

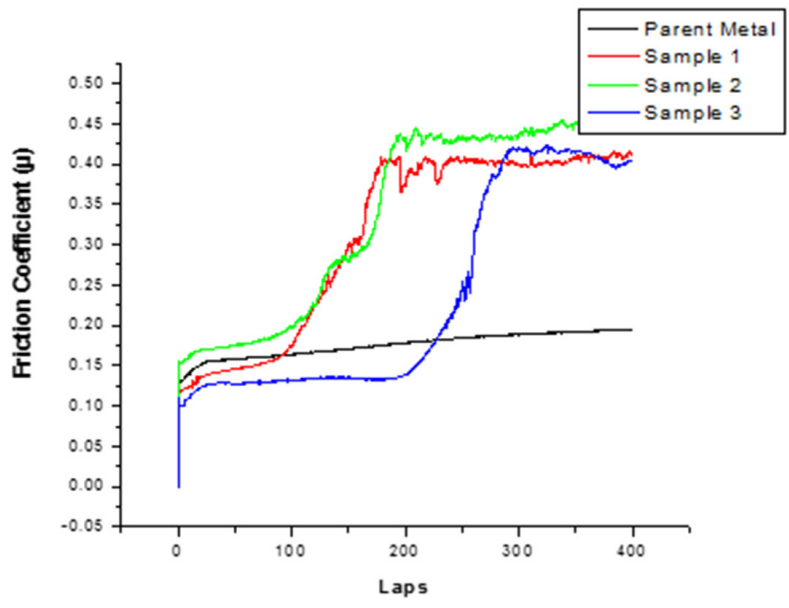

Figure 8. Friction coefficient results of the parent metal and friction-stir welded joint three samples. 


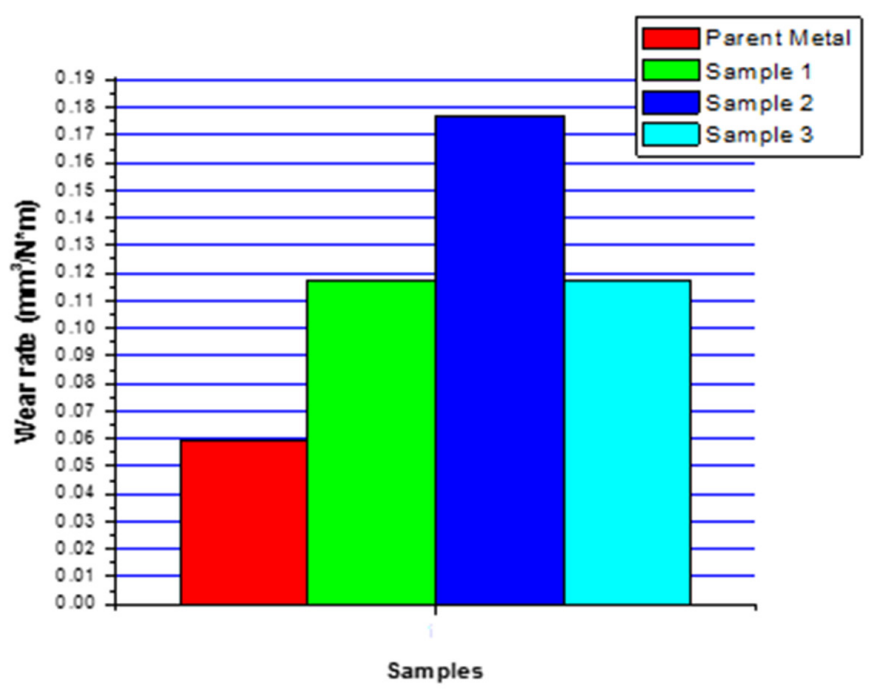

Figure 9. Wear rate of the samples and the parent metal and friction-stir welded joint three samples.

It was found that the wear rate of friction stir welded joints of the A359/SiC/20p AMC increase with the welding parameters (rotational speed tool, welding speed and axial force) use in this study. The increase is due to the microstructure coarsening in the welded zone. This is due to the recrystallization in consequence of the high frictional heat input produced at high rotational speed. It is well known by the reference of other studies [20,21] that the grain refinement in weld zone is achieved employing low rotational speed. The stage of grain growth is reached during recrystallization process and a relatively coarse grain microstructure is obtained due to the high temperature produced during the increasing of the tool rotational speed. The formation of voids and cracks at the coarse matrix/SiC particle interface occurs by the high stirring, and also support the liberating and separating of the reinforcement particles throughout sliding conditions, therefore, causing the decaying of wear resistance [12].

Welding speed controls the exposure time of frictional heat per unit length of the weld and hence has influence in the grain growth [17]. When lower welding speed is applied higher heat is produced due to the longer exposure time to frictional heat per unit length of the weld area and rate of cooling is decreased, then generates coarsening of grains after recrystallization, which reduces the wear resistance of the friction stir welded joints of the AMC.

\section{Conclusions}

In this study was analyzed the dry sliding wear resistance on the friction stir welded joints of the considered composite of aluminum A359 matrix reinforced with SiC particles at a rate of $20 \%$ by in weight: The conclusions are the following:

1. It can be seen the friction coefficient and the wear rate of the base metal are lower than the friction stir welded joints; therefore, the wear resistance of the friction stirred welded joints increases compared to the parent metal.

2. High rotational speed causes the wear rate of the welded joint increases. The microstructure coarsening is the cause on the reduction of the wear resistance of the welded joints at high tool rotational speed. In addition, the high stirring will let the formation of voids, cracks at the coarse matrix/SiC particle interface, that support the liberating and separating of the reinforcement particles during stirring, it causes the reduction in the wear resistance of the AMC friction-stir welded joints.

\section{References}

[1] Prater T. Friction stir welding of metal matrix composites for use in aerospace structures. Acta Astronautica. 2014;93:366373. http://dx.doi.org/10.1016/j.actaastro.2013.07.023.
[2] Kim YG, Fujii H, Tsumura T, Komazaki T, Nakata K. Effect of welding parameters on microstructure in the stir zone of FSW joints of aluminum die casting alloy. Materials Letters. 
2006;60(29-30):3830-3887. http://dx.doi.org/10.1016/j. matlet.2006.03.123.

[3] Kavorkijan V. Engineering wear-resistant surfaces in automotive aluminum. JOM. 2003;55(2):32-34. http://dx.doi.org/10.1007/ s11837-003-0223-7.

[4] Hayajneh M, Hassan AM, Alrashdan A, Mayyas AT. Prediction of tribological behavior of aluminum-copper based composite using artificial neural network. Journal of Alloys and Compounds. 2009;470(1-2):584-588. http://dx.doi.org/10.1016/j. jallcom.2008.03.035.

[5] Hoa SV. Principles of the manufacturing of composite materials. Lancaster: DEStech Publications; 2009. 352 p.

[6] Storjohann D, Barabash OM, David SA, Sklad PS, Bloom EE, Babu SS. Fusion and friction stir welding of aluminum-metal-matrix composites. Metallurgical and Materials Transactions. A, Physical Metallurgy and Materials Science. 2005;36(11):3237-3247. http://dx.doi.org/10.1007/s11661-005-0093-4.

[7] Thomas WM, Nicholas ED, Needham JC, Murch MG, TempleSmith P, DAWES CJ, inventors. Friction-stir butt welding. Great Britain Patent Application No. 9125978.8. 1991.

[8] Mishra RS, Mahoney MW, editors Friction stir welding and processing. Materials Park: ASM International; 2007. 352 p.

[9] Thomas WM, Johnson KI, Wiesner CS. Friction stir weldingrecent developments in tool and process technologies. Advanced Engineering Materials. 2003;5(7):485-490. http:// dx.doi.org/10.1002/adem.200300355.

[10] Berbon PB, Bingel WH, Mishra RS, Bampton CC, Mahoney MW. Friction stir processing: a tool to homogenize nanocomposites aluminum alloys. Scripta Materialia. 2001;44(1):61-66. http:// dx.doi.org/10.1016/S1359-6462(00)00578-9.

[11] Dawes CJ, Thomas WM. Friction stir process welds aluminum alloys. Welding Journal. 1996;75:41-45.

[12] Sawla S, Das S. Combined effect of reinforcement and heat treatment on the two body abrasive wear of aluminum alloy and aluminum particle composites. Wear. 2004;57(5-6):555561. http://dx.doi.org/10.1016/j.wear.2004.02.001.
[13] Suresh S, Mortensen A, Needleman A, editors. Fundamentals of metal-matrix composites. Stoneham: Butterworth-Heinemann; 1993. $311 \mathrm{p}$.

[14] Rohatgi PK, Schultz BF, Daoud A, Zhang WW. Tribological performance of A206 aluminum alloy containing silica sand particles. Tribology International. 2010;43(1-2):455-466. http:// dx.doi.org/10.1016/j.triboint.2009.07.010.

[15] Alaneme KK, Adewale TM. Influence of rice husk ash/silicon carbide weight ratios on the mechanical behavior of aluminum matrix hybrid composites. Tribology in Industry. 2013;35(2):163172.

[16] Cuevas Mata O, Miranda Pérez AF, García Vázquez FJ, Pérez Medina GY, Reyes Valdés FA. Effect of FSW parameters on microstructure of aluminum matrix composites joints. In: Pérez Campos R, Contreras Cuevas A, Esparza Muñoz R, editors. Materials characterization. Switzerland: Springer International Publishing; 2015, p.139-146. http://dx.doi.org/10.1007/978-3319-15204-2_14.

[17] Murugan N, Kumar AB. Optimization of friction stir welding process parameters to maximize tensile strength of stir cast AA6061-T6/Al Np composite. Material and Design. May 2014;57:383-393.

[18] ASTM International. ASTM G99-05: Standard test method for wear testing with a pin-on-disk apparatus. West Conshohocken: ASTM International; 2016. p. 1-5.

[19] Archard JF. Contact and rubbing of flat surfaces. Journal of Applied Physics. 1953;24(8):981. http://dx.doi.org/10.1063/1.1721448.

[20] Prasad SV, Asthana R. Aluminum metal-matrix composites for automotive applications: tribological considerations. Tribology Letters. 2004;17(3):445-453. http://dx.doi.org/10.1023/ B:TRIL.0000044492.91991.f3.

[21] Xiu Z, Yang W, Chen G, Jiang L, Ma K, Wu G. Microstructure and tensile properties of Si3N4p/2024Al composite fabricated by pressure infiltration method. Materials \& Design. 2012;33:350355. http://dx.doi.org/10.1016/j.matdes.2011.03.001. 